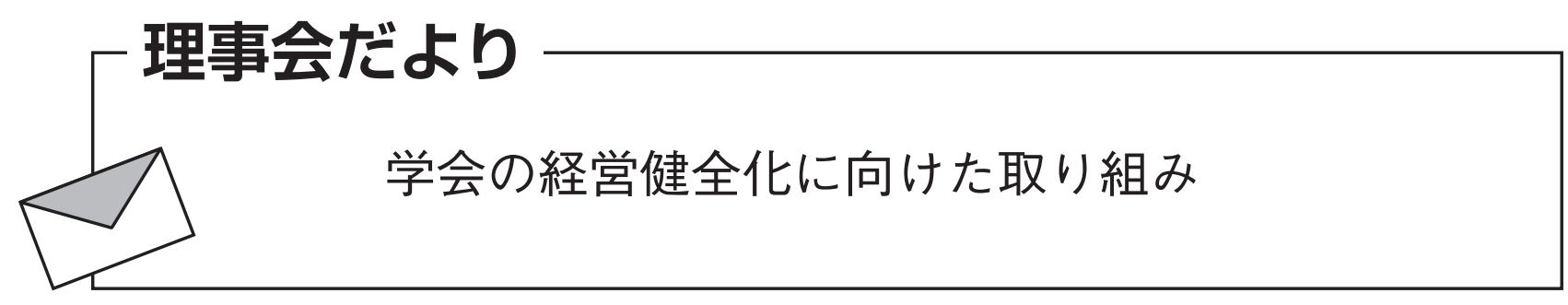

経営改善特別小委員会の活動と成果

日本原子力学会 (以下「学会」) では, 平成 23 年 3 月 11 日に発生した東京電力福島第一発電所の事故後の原子力 界を取り巻く環境の激変に伴い，財務状況の急激な悪化 が懸念される事態となりました。このため財務改善WG を設置して，外部の専門家による財務診断も含めた収支 バランス改善策を実施し，当面の収支を改善しました。

さらに，平成 23 年度下期に制度検討タスクを設置し， 根本的な財務改善策を制度面から検討し，事務局長公 募, 理事事務局長の設置, 学会運営の基本方針, 事務局 改革の方針を取りまとめました。

これを受けて, 平成 24 年 1 月の理事会で, 「経営改善 特別小委員会 (以下「小委員会」)」の設置を決定しました。

小委員会では, 平成 24 年度には, 公認会計士抢よび社 会保険労務士とコンサルタント契約を結んで，具体的な 改革案の提案を受け，それに基づき順次，改善策を進め ました。以下にその主な内容について示します。

\section{1. 事務局員の給与体系の見直し}

原子力学会は社団法人であったことから事務局員の給 与体系，雇用形態は，国家公務員のそれを参考に定めら れていました。平成 23 年度から一般社団法人に移行し たこともあり，事務局職員の理解を得て，給与体系，働 き方を民間並みに変更し, 関連する規程類の改定, 人事 考課システムを更新しました。

\section{2. 事務局業務の合理化}

1 . 項の改革は, 事務局経費の削減をその目的の一つ としていますが，抜本的には事務局が担う業務そのもの を削減することが必要との認識のもとに, 経理書類の簡 素化, 外部委託によるさらなる合理化, 会員管理システ ムの更新等を検討し, 実行可能なものから順次とりいれ ました。

\section{3，学会誌編集委員会の経費節減}

このところ，学会誌ATOMO $\Sigma$ の表紙の変化に扬気 づきの方も多いと思いますが，学会誌の印刷の競争入札 化や，表紙デザインの簡素化等で，印刷費を削減した結 果です。また，編集管理や記事校閲に携わって頂いてい る方々への報酬支払いの制度も見直しました。

\section{4. 組織のガヴァナンス強化}

一般社団法人としての学会の諸活動に関して, 日常的 な活動の責任は総会において選任された理事会に託され ていますが，そのためには必要な情報が理事会に提供さ れる必要があります。一方，諸活動の活性化のために
は，大きな経営上のリスクを伴わない活動については， 各組織が自主的に判断したり，得られた収益を次の活動 に柔軟に活用したりできることも重要です。このため, 諸規定を見直して，締めるところと任せるところのメリ ハリを持たせました。一例として，各組織へ配分されて いる予算の使い道, 次年度への繰り越しに柔軟性を持た せたことが挙げられます。

5. 会員増強策, 収入増加策

正会員については，会員の年齢構成，今後の新規加入 者の予測から，非常に厳しい状況にあることを認識しつ つも，残念ながら有効な対策はまだとれていません。賛 助会員も厳しい状況にありますが，今後は除染や廃炉関 連事業で新しい企業の参入も予測されるため, $\mathrm{OB}$ 会員 に業務委託して会員開拓を進めています。

\section{6. 標準活動運営委員会の設立}

学会標準の制定・改定を中心とする標準活動は，その 性格上, 中立性が求められることから, 理事会の係わり 方は他事業に比べ弱いものでした。しかし，学会として の活動の一貫性も重要であり, 理事会と標準活動の連携 を深めるため, 本小委員会を発足させました。

\section{7. 新規事業の開拓}

学会に相応しい新規事業の開拓の検討も進めており, 翻訳の際の専門用語監修の支援等を始めています。

8. 魅力ある学会に向けて

発足以来, ホームページの改善を課題として議論を重 ね会員サービス委員会に引き継ぎました。

さらに，学会の最大行事である「春の年会」「秋の大 会」を一層魅力的にする方策の検討を始めました。具体 化は関倸組織にお願いすることになりますが，問題提起 と方向性の提示は, 当小委員会で進める所存です。

以上，列挙してみましたが，諸施策の結果，間接経費 といえる管理費は, 平成 23 年度の 9,000 万円強から平成 25 年度には 6,500 万円強へと，大きく削減することがで きました。また，学会全体の収支に関しても，年会等の 参加費の改定, 部会費制度の変更等で会員の皆様のご協 力を得た結果，黑字基調が定着しつつあり，今後は諸事 業の活性化に向けた取り組みが必要と考えています。

(理事・経営改善特別小委員会委員長 百々 隆)

「理事会だより」へのご意見，ご提案の送り先 rijikaidayori@aesj.or.jp 